figure that the cure for unemployment is the repeal of the Adamson Law, or that the cure is something somebody else can do. It might be, but if it does not happen to be, you have left yourself out in the cold; none of us does his share unless he figures that share to be a little bigger than it really is. The job is up to us! There is much the government can do; there is much the financial group can do; but the greatest share of the job is ours and if we are going to call ourselves managers, let's put mind and soul to this big task of solving one of the most pressing and vital problems of every industry.

The present condition of unemployment is so serious and is such an indictment against the social system that $I$ earnestly urge you to remember for the next two years, during which the real preventive work must be done, that it is up to you-up to every one of us- to take effective measures so that the next depression will not find us so ill-prepared, will not find us having learned so little from all the depressions that have occurred in the past.

\title{
The Russian Famine Region
}

\author{
By Vernon Kellogg \\ Special Investigator for the American Relief Administration in Russia
}

$\mathrm{O}$ NE can judge of the situation in a country in which there is an alleged famine by either one or both of two ways. One can study in an office the figures of normal production and consumption and compare them with abnormal production and get a very fair idea of what the food situation must be in the affected region. For example, in the single province, or government, in Russia, of Samara on the Volga river, the annual pre-war production of grain (wheat, rye, oats and barley) was about 120,000,000 poods (a pood is 36 pounds); in 1920 it was $18,000,000$ and in $1921,3,000$,000. That is just about enough to feed all the people of this province, if this $3,000,000$ poods of grain were equally distributed, for one and a half months. Under such conditions there is bound to be famine unless some food is coming in from the outside.

But there is another way to estimate the situation in a country claiming to be suffering from hunger. That is to see the fields and warehouses and markets and the people themselves.
When you start from Moscow towards the Volga river across the broad plains to the east of the great city, you soon become aware of the peculiar apathy and deadness of the people at the trains; and as you get further along, your attention is unescapably attracted by groups who are camping by the railroad and at the railroad stations. These are the so-called refugee campsterrible sights. These are the people who, in panic, are trying to flee from the famine region and who have got this far. And when you finally reach the Volga itself, you will find more refugee camps along the river-a broad, slow, muddy river rather like our Colorado of the West after it leaves the cañons and gets out on the desert. All along this river on which move still a few heatless, lightless, foodless boats, there are many of these camps of men, women and children who want to be taken away anywhere on the boats. The people in the camps have a certain kind of food with them. It is their bread, black, sticky, awful, made of bark and bits of roots and leaves and of "clay"-really humus. 
They are living on this and some potatoes and cabbages.

When you analyze these groups, you are struck by this fact: that half the people in these refugee camps are peasants and peasants' families. They are the people who come from the sources of food; the fields in which food is produced, if any is produced. Almost always in relief work the people who have to be helped are those in the cities, the workless working people, the industrials who have no money to buy food at the high famine prices. But here in Russia, before you get into the famine region itself, you know there is famine by finding out that the refugees are the peasants themselves, the food producers.

\section{The Need of the Children}

It is not my intention to harass you with stories of the dreadful things one sees in the Russian famine region. Just one little picture that will not leave my eyes. The people are trying to take special care of the childrenhungering people always try to do this -and so they have set up children's homes in towns along the Volga. Children are picked up on the streets, orphans in fact or orphaned in effect by being deserted by parents unable to feed them, or they are brought to the homes by the despairing parents. The parents are not killing their children and eating them, as has been reported in some newspaper stories, but they are giving them up. And the children are collected in these homes-bare, heatless buildings-with very little food but all that the few brave women who are trying to take care of them can get.

In Children's Home No. 5 in Samara I happened to come in just at the time for the noon meal. This was composed of horse meat-the farmers are killing their farm animals which they cannot feed-and grits. All the children were sitting on the floor in a large bare room, most of them with their backs to the wall in a pitiful line about the room. There were three cots in this room and four children were lying on one, three on another and three on another. After they had eaten their meal, I said to one of the women, "Where do they go now?" "They stay here," she said. "Where do they sleep?" "They sleep here." "Do you bring in mattresses and blankets?" I asked. "We have no mattresses and blankets," she replied. "Is this all the food they have?" And she answered, "Yes, when they have any food at all." When I told these women that the next day they would have rice with sugar and milk and white bread from America, they broke down.

The whole situation is incredible to those who have not seen it; it is beyond description by those who have. The region affected includes at least fifteen million people; it includes a large part of seven great provinces of Russia and around this central famine region there is a region of fifteen million more in which there is a food shortage. This came about, in the first place, by the devastation of six years' constant international and civil war; in the second, by the fatal error of the Soviet government-I do not hesitate to speak thus plainly, for the government itself admits it today-of trying" to requisition the surplus production of the peasants all over the country and of prohibiting private trading. Hence the peasants have had no stimulus to produce more than just enough for themselves. The whole agricultural production of Russia has dropped terribly in the last three years because of this fatal mistake. Finally, on top of these causes of food shortage came a drought so real and terrible that there are miles and miles of fields 
that were planted in grain in the spring which the peasants have not even tried to enter to harvest.

In normal times the Volga basin is a grain-exporting region, and now fifteen million people in it are crying for help. The government has made an effort to bring food into the famine region from other parts of Russia, but there is no surplus of food in other parts of Russia except, perhaps, in the Ukraine; and in much of the Ukraine the Soviet government is without power. $\mathrm{A}$ famous bandit rules there. The government also tried to bring in seed for the fall planting but it succeeded in getting into the peasants' hands only about one-fifth enough seed for a normal planting.

\section{Inadequacy of Present Relief}

What is the world to do to help the Russian peasants at this time? What is it doing? An International Commission has been organized. It has held meetings in Geneva and Brussels, but not one cent of money or one pound of food has been provided by this International Commission. The
Swedish Red Cross is sending in a Red Cross unit. Norway has given one million kronen. The Save the Children League of England has put in $\mathrm{Mr}$. Nansen's hands money enough to buy food for 250,000 children for six months: that is about the total of European relief.

America has a better record. The American Friends' Service Committee has been at work to the best of its ability, doing a beautiful work as far as it goes, but handicapped always by lack of resources. And, finally, the American Relief Administration, under the chairmanship of $\mathrm{Mr}$. Hoover, is now feeding one million children and will be able to do this until the first of next September, the time of the next harvest. But there are four million children who ought to be cared for; and there are the mothers and fathers of these children to be cared for.

The world is letting this people die because we do not send from America and Roumania and Bulgaria, where there is a surplus of grain today, the food to keep them alive. Shall we let this go on? 